\title{
Development of a sensitive Luminex XMAP- based microsphere immunoassay for specific detection of Iris yellow spot virus
}

\author{
Cui Yu ${ }^{1 *}$, Cuiyun Yang ${ }^{1}$, Shaoyi Song ${ }^{1}$, Zixiang Yu' ${ }^{1}$ Xueping Zhou ${ }^{2,3}$ and Jianxiang $\mathrm{Wu}^{2^{*}}$
}

\begin{abstract}
Background: Iris yellow spot virus (IYSV) is an Orthotospovirus that infects most Allium species. Very few approaches for specific detection of IYSV from infected plants are available to date. We report the development of a high-sensitive Luminex XMAP-based microsphere immunoassay (MIA) for specific detection of IYSV.

Results: The nucleocapsid ( $M$ ) gene of IYSV was cloned and expressed in Escherichia coli to produce the His-tagged recombinant $\mathrm{N}$ protein. A panel of monoclonal antibodies (MAbs) against IYSV was generated by immunizing the mice with recombinant N protein. Five specific MAbs (16D9, 11C6, 7F4, 12C10, and 14H12) were identified and used for developing the Luminex XMAP-based MIA systems along with a polyclonal antibody against IYSV. Comparative analyses of their sensitivity and specificity in detecting IYSV from infected tobacco leaves identified 7F4 as the best-performed MAb in MIA. We then optimized the working conditions of Luminex XMAP-based MIA in specific detection of IYSV from infected tobacco leaves by using appropriate blocking buffer and proper concentration of biotin-labeled antibodies as well as the suitable ratio between the antibodies and the streptavidin R-phycoerythrin (SA-RPE). Under the optimized conditions the Luminex XMAP-based MIA was able to specifically detect IYSV with much higher sensitivity than conventional enzyme-linked immunosorbent assay (ELISA). Importantly, the Luminex XMAP-based MIA is time-saving and the whole procedure could be completed within $2.5 \mathrm{~h}$.
\end{abstract}

Conclusions: We generated five specific MAbs against IYSV and developed the Luminex XMAP-based MIA method for specific detection of IYSV in plants. This assay provides a sensitive, high-specific, easy to perform and likely cost-effective approach for IYSV detection from infected plants, implicating potential broad usefulness of MIA in plant virus diagnosis.

Keywords: Iris yellow spot virus, Antibody, Microsphere immunoassay, Detection

\section{Background}

Orthotospoviruses infect a wide range of plant species and are among the most serious threats to vegetable crops. Iris yellow spot virus (IYSV) is an Orthotospovirus in the family Tospoviridae of the order Bunyavirales, which has been reported to infect most Allium species such as onion crops and some ornamentals such as Spiny Sowthistle, Irises and Lisianthus [1-3]. IYSV was firstly recorded in onion crops in Idaho, USA in 1989 [4] and then in the Netherlands in 1992, where it was

\footnotetext{
* Correspondence: yuc@shciq.gov.cn; wujx@zju.eud.cn

'Shanghai Entry-Exit Inspection and Quarantine Bureau, Shanghai 200135, China

${ }^{2}$ Institute of Biotechnology, Zhejiang University, Hangzhou 310058, China Full list of author information is available at the end of the article
}

characterized to be a new, distinct orthotospovirus from Iris hollandica [5]. Subsequently, IYSV was found to occur in [6] Brazil [7], Australia [8], Japan [9], Chile [10], Spain [11], Guatemala [12], Peru [13], India [14], and Egypt [15].

The symptoms caused by IYSV in Allium spp. include yellow- to straw-coloured, diamond-shaped lesions on infected leaves and flowering scapes [1]. Diamondshaped lesions are particularly pronounced on infected scapes and gradually merge along the disease progresses, eventually leading to the lodging of infected scapes. In seed crops, this would lead to a severe reduction in yield and quality. Early to mid-season infection in bulb crops results in reduced vigour and bulb size [16]. To date, two thrips species, Frankliniella fusca and Thrips tabaci 
(Thysanoptera: Thripidae), have been experimentally proved to be able to transmit IYSV [17]. Nowadays, IYSV has been emerging as a severe threat to the onion crop in the world $[1,16]$.

One of the prerequisites to develop the management strategies for controlling Orthotospoviruses is to develop accurate diagnose and identification methods. Unlike Tomato spotted wilt virus (TSWV), IYSV infections typically do not become systemic in onion or other host species. The enzyme-linked immunosorbent assay (ELISA)-based technique has been developed for IYSV detection [18]; however, ELISA assays are time-consuming, laborious and error-prone due to its low sensitivity and potential false negative results. Nucleic acid-based approaches such as RT-PCR and real-time PCR are also available for detecting and identifying IYSV $[13,19]$, but the use of PCR-based approaches for the high-throughput detection of IYSV is uneasy and time-consuming in practice when a large number of samples are handled simultaneously.

In the past several years, the microsphere immunoassay (MIA) based on the xMAP (Flexible multi-analyte profiling) technology has emerged as an alternative for detection of microbial pathogens. This system involves covalent coupling of an antigen or antibody on carboxy-lated polystyrene microspheres that are internally dyed with a fluorophore, which consists of as many as 100 unique beads/microspheres and has the potential for simultaneous (multiplex) detection of 100 different targets [20]. The detection of microspheres is implemented by two lasers, one for identifying the color of the microsphere and determining the type of the objects, another for determining the intensity of the microspheres and the quantity of the objects. To date, several studies that use this technology to detect multiple targets in plants have been reported [21-23]. However, the xMAP-based MIA method for detection of Orthotospoviruses (including IYSV) has not been available yet.

In this study, we report the generation of a set of monoclonal antibodies (MAbs) and polyclonal antibody against IYSV. Based on these antibodies, we developed a Luminex xMAP-based MIA for high-throughput detection of IYSV. We compared the sensitivity and specificity of MIA with the conventional triple antibodiesbased sandwich (TAS)-ELISA in detecting IYSV, and demonstrated that the MIA method we developed show better performance.

\section{Methods}

Virus isolates

The virus sources of IYSV, TSWV and Impatiens necrotic spot virus (INSV) were kindly supplied by Professor R. Kormelink (Wageningen Agricultural University, The
Netherlands). The viruses were maintained and multiplicated in Nicotiana benthamiana plants by our laboratory as previously described. Positive controls of IYSV, TSWV and INSV were purchased from DSMZ (Germany). Arabis mosaic virus (ArMV), Tobacco ringspot virus (TRSV) and Strawberry latent ringspot virus (SLRSV) were used for validating the specificity of the microsphere immunoarray.

\section{Cloning and expression of the $\mathbf{N}$ gene of IYSV in Escherichia coli}

To clone the $N$ gene of IYSV, a pair of primers FCP-F (CCATATGGATGTCTACCGTTAGGGTGAAACC, the Nde I site was underlined) and FCP-R (CAAGCTTGTTAATTATATCTATCCTTCTTGGAGG, the Hind III site was underlined) were designed and synthesized based on the reported genomic sequence of IYSV ( $N$ gene, GenBank accession No. AB505813). Total RNAs were extracted from IYSV-infected tobacco plants using RNeasy Plant mini Kit (Qiagen, Hilden, Germany), and RT-PCR was performed using the One-Step RT-PCR system (Takara, Dalian, China) according to the manufacturer's instruction using the primers FCP-F and FCPR. PCR products were purified using gel extraction columns (Qiagen, Hilden, Germany). The purified PCR product was digested with Nde I and Hind III, and cloned into $6 \times$ His-tagged prokaryotic expression vector pCold II (Novagen, Darmstadt, Germany). The recombinant expression vector pCold II-IYSV-N was transformed into Escherichia coli pG-TF2 strain (GE Healthcare, Bucks, UK). And recombinant $\mathrm{N}$ protein was produced by induction with $1 \mathrm{mM}$ isopropylthio-b-galactosidebovine (IPTG) at $15{ }^{\circ} \mathrm{C}$ overnight. The recombinant $\mathrm{N}$ protein was purified using Ni-NTA agarose as instructed by the manufacturer (Qiagen, Hilden, Germany).

\section{Production of polyclonal antibody}

Two rabbits were immunized with purified IYSV recombinant $\mathrm{N}$ protein. For the first subcutaneous injection, $0.8 \mathrm{mg}$ purified recombinant $\mathrm{N}$ protein in $1 \mathrm{ml}$ phosphate-buffered saline (PBS) was emulsified with an equal volume of complete Freund's adjuvant (Sigma-Aldrich). Subsequently, the recombinant protein $(0.5 \mathrm{mg}$ in $1 \mathrm{ml} \mathrm{PBS}$ ) emulsified with an equal volume of incomplete Freund's adjuvant (Sigma-Aldrich) was administered at 3-week interval for three times. Rabbits were bled 1 week after the fourth injection, and the sera were used in TAS-ELISA.

\section{Preparation of hybridomas secreting MAbs}

Intraperitoneal immunizations of $25 \mu \mathrm{g}$ purified recombinant protein were administered to four femal BALB/c mice with complete Freund's adjuvant for the primary immunization and incomplete Fruend's adjuvant for 
subsequent boosts. Hybridomas secreting MAbs against IYSV recombinant nucleocapsid protein were produced by fusion of spleen cells from immunized BALB / c female mice and the mouse myeloma cell line SP2/0 as previously described [24]. Hybridoma supernatants were screened for the presence of specific antibodies against recombinant $\mathrm{N}$ protein as detected by an indirect-ELISA as described by Jiang et al. [25]. The specific positive hybridoma cells were cloned with the method of the limiting dilution [26] for more than three times to get the hybridoma lines that produce the MAb against the $\mathrm{N}$ protein of IYSV.

\section{Production of MAbs in ascitic fluids}

Hybridoma cells were injected intraperitoneally into mineral oil-primed BALB/c mice to produce the ascites. At 7-10 days after the injection the ascitic fluids were collected and tested for their titre by indirect-ELISA [27] using purified recombinant $\mathrm{N}$ protein of IYSV as antigen. The isotypes of the MAbs were determined by double immunodiffusion assay with the mouse MAb isotyping reagents according to the manufacturer's instruction (Sigma-Aldrich). The specificity of the MAbs was further determined by Western blot analysis using IYSVinfected and healthy plant tissues as the antigens and negative controls, respectively.

\section{SDS-PAGE and Western blot}

The purified recombinant $\mathrm{N}$ protein was analyzed by sodium dodecyl sulfate-polyacrylamide gel electrophoresis (SDS-PAGE) followed by either.

Coomassie blue R-250 staining or Western blot analysis after transferred to a nitrocellulose membrane (GE Healthcare) using a Trans-blot SD Semi-Dry transfer Cell (Bio-Rad). IYSV MAbs or anti-His tag MAb (1:1000, Novagen) was used for Western blot analysis.

\section{ELISA}

Detection of viruses was carried out following the standard procedures TAS-ELISA [28]. The sample was considered to be positive when its $\mathrm{OD}_{405}$ value was greater or equal to 2 times of the mean value from negative controls. Each sample was independently repeated two times.

\section{Coating of magnetic beads with polyclonal antibody and coupling biotin to MAbs}

The purified antibodies from the rabbit polyclonal IYSV were coupled with specific MagPlex microsphere Set (BioRad) according to the instruction manual. Briefly, about 2000 microsphere beads were washed with activation buffer twice and then activated with Sulfo-Nhydrosuccinimide (sulfo-NHS) and N- [3-dimethylaminopropyl]- $\mathrm{N}^{\prime}$ - ethylcarbodiimide hydrochloride (EDC) by shaking for $20 \mathrm{~min}$ at room temperature. Approximately
$12 \mu \mathrm{g}$ antibodies were added to the activated beads and incubated $2 \mathrm{~h}$ at room temperature. The success of the coupling reaction was evaluated by detection of the coupled rabbit IgG with a phycoerythrin-conjugated goat anti-rabbit antibody. The MAbs against IYSV were biotinylated with the Thermo Fisher EZ-Link Sulfo-NHS-LCBiotin Reagent (Cat. No. PI-21335) according to the standard procedure provided by the manufacture.

\section{Microsphere immunoassay}

The whole process of MIA detection was carried out in a 96-well plate (Tellgen, Shanghai, China). The samples were prepared by grinding $0.1 \mathrm{~g}$ fresh tissue or $0.01 \mathrm{~g}$ lyophilized tissue in $1 \mathrm{~mL}$ PBS with BSA (PBS-TBN, $8 \mathrm{~g}$ $\mathrm{NaCl} / \mathrm{L}, 0.2 \mathrm{~g} / \mathrm{L} \mathrm{KCl}, 1.44 \mathrm{~g} / \mathrm{L} \mathrm{Na}{ }_{2} \mathrm{HPO} 4$ and $0.24 \mathrm{~g} / \mathrm{L}$ $\mathrm{KH}_{2} \mathrm{PO}_{4}$, with BSA 1\%, pH 7.4). The samples were centrifuged at $14,000 \mathrm{~g}$ for $5 \mathrm{~min}$ and the supernatant was placed in a new tube. The microspheres coated with the antibody were vortexed for $30 \mathrm{~s}$ at full speed and then diluted in PBS -TBN to prepare the work solution at $8 \times$ $10^{4}$ beads/mL. In order to be detected with the X-map analyzer, the biotinylated MAbs were also coupled with streptavidin R-phycoerythrin (SA-RPE) in the assay. To do this, the concentration of the MAbs labeled with biotin was adjusted to about $20 \mu \mathrm{g} / \mathrm{mL}$ and labeled with SA-RPE with the ratio $1: 0.2$ at $4{ }^{\circ} \mathrm{C}$ for $1 \mathrm{~h}$.

To establish the assay for detection of IYSV, $25 \mu \mathrm{L}$ PBS-TBN, $10 \mu \mathrm{l}$ sample saps and $25 \mu \mathrm{L}$ SA-RPE-labeled antibodies were mixed and reacted at $37{ }^{\circ} \mathrm{C}$ for $5 \mathrm{~min}$. Then, $25 \mu \mathrm{L}$ beads work solution was added and the reactions were continued for $60 \mathrm{~min}$ at $37{ }^{\circ} \mathrm{C}$. The median fluorescent intensity (MFI) of each reaction was measured and analyzed with 100 beads per well, using the Bio-plex 200 system (Bio-Rad).

\section{Comparison between ELISA and MIA for detecting IYSV}

The sensitivity of TAS-ELISA and MIA in detecting IYSV was evaluated with a same set of samples. Crude extracts from IYSV-infected leaf tissues were diluted with crude extracts from non-infected tobacco leaves to generate a dilution series. A same set of samples were then tested by TAS-ELISA and MIA, respectively. Buffer and negative controls were included in each set of reactions to verify the reaction performance.

\section{Results}

Production of recombinant IYSV N proteins in E. coli

The 822-bp full-length $N$ gene of IYSV was amplified by RT-PCR using the total RNAs extracted from the IYSVinfected tobacco leaves. The sequence confirmed $\mathrm{N}$ gene was then subcloned into the protokarytic expression vector pCold II and introduced into the E.coli strain pG-TF2. After induction by adding IPTG, SDS-PAGE and Western blot analysis confirmed that the recombinant $\mathrm{N}$ protein 
was properly expressed in the E.coli strain pG-TF2 harboring pCold II-IYSV-N (Fig. 1). The His-tagged recombinant $\mathrm{N}$ proteins were affinity-purified using Ni-NTA agarose and eluted by imidazole.

\section{Generation of MAbs against recombinant IYSV N proteins}

To generate the highly specific MAbs against IYSV, we used $25 \mu \mathrm{g}$ recombinant $\mathrm{N}$ proteins to immunize the mice. After 6 months, five hybridoma cell lines (7F4, 11C6, 12C10, 14H12, 16D9) secreting MAbs against recombinant IYSV $\mathrm{N}$ proteins were obtained. Immunodiffusion assay showed that four MAbs (7F4, $12 \mathrm{C} 10,14 \mathrm{H} 12,16 \mathrm{D} 9)$ belonged to the subclass IgG1, whereas 11C6 was classified into the subclass IgG $2 \mathrm{a}$. The light chains of all the five MAbs belonged to k-chain.

We then determined the titres of ascitic fluids of MAbs by TAS- ELISA and found they were ranged from $10^{-5}$ to $10^{-7}$. The IgG yields of these five MAbs from ascitic fluids were also determined, with the MAb $14 \mathrm{H} 12$ showing the highest yield of $42.5 \mathrm{mg} / \mathrm{ml}$ and the 16D9 producing the least $(20.33 \mathrm{mg} / \mathrm{ml})$ (Table 1$)$.

To test the specificity of the MAbs we obtained, we carried out the Western blot analyses. As shown in Fig. 2, all the five MAbs could strongly and specifically detect the recombinant IYSV $\mathrm{N}$ proteins from total extracts of E. coli, producing the sole band with molecular weight of approximately $32 \mathrm{kDa}$, indicating that the five MAbs we obtained could specifically recognize the recombinant IYSV $\mathrm{N}$ protein.

\section{Development and optimization of MIA in detecting IYSV}

Previous study has demonstrated that some antibodies can be used for ELISA assays but may be not suitable for development of the MIA [29]. Therefore, the
Table 1 Properties of MAbs against recombinant N protein of IYSV

\begin{tabular}{|c|c|c|c|}
\hline MAbs & Isotype & Titre & Yield of lgG in ascitic fluid $(\mathrm{mg} / \mathrm{mL})$ \\
\hline$\overline{7 F 4}$ & $\lg$ G1, $\mathrm{k}$ chain & $10^{-5}$ & 35.25 \\
\hline $11 C 6$ & $\operatorname{lgG} 2 a, k$ chain & $10^{-6}$ & 20.57 \\
\hline $12 C 10$ & $\lg G 1, \mathrm{k}$ chain & $10^{-7}$ & 26.33 \\
\hline $14 \mathrm{H} 12$ & $\operatorname{lgG} 1, k$ chain & $10^{-7}$ & 42.50 \\
\hline $16 \mathrm{D} 9$ & $\lg$ I, $\mathrm{K}$ chain & $10^{-7}$ & 20.33 \\
\hline
\end{tabular}

identification of an appropriate antibody against the target is critical for developing a reliable and practical MIA assay. To determine which MAbs against IYSV is more suitable for the MIA detection, we coupled microspere with the IYSV rabbit antibodies and labeled MAb with biotin, respectively. The results showed that the rabbit antibody-coated microsphere and SA-RPEcoupled 7F4 had high MFI value to sample and low MFI value to buffer control, while the MAbs 11C6 and $12 \mathrm{C} 10$ followed in the performance. Thus, we subsequently used the MAb 7F4 to optimize the MIA assay. We adjusted the concentration of 7F4-biotin and the quality ratio between the 7F4-biotin and streptavidin R-phycoerythrin (SA-RPE), and established that the optimal concentration of biotin-labeled 7F4 was $6 \mu \mathrm{g} / \mathrm{mL}$ and the quality ratio between the biotin-labeled 7F4 and SA-RPE is 1:0.3. Then, we evaluated the specificity of MIA in detecting IYSV by conducting comparative assays. Three Nepoviruses including ArMV, TRSV and SLRSV as well as two other Orthotospoviruses including INSV and TSWV were used. We found that the MIA system could only detect the leaf samples infected by IYSV, but not those infected by other six viruses (Table 2), indicating that the MIA method we developed has high specificity in detecting IYSV.

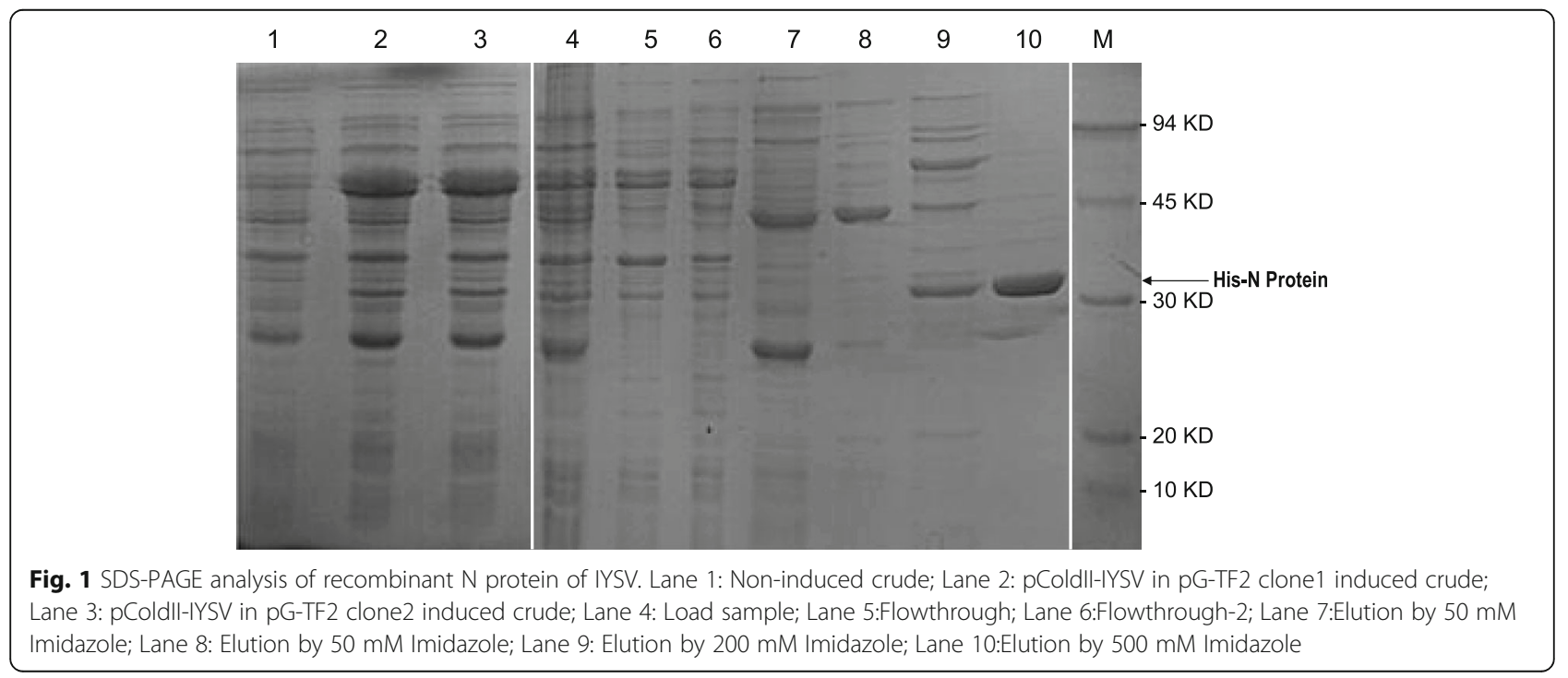




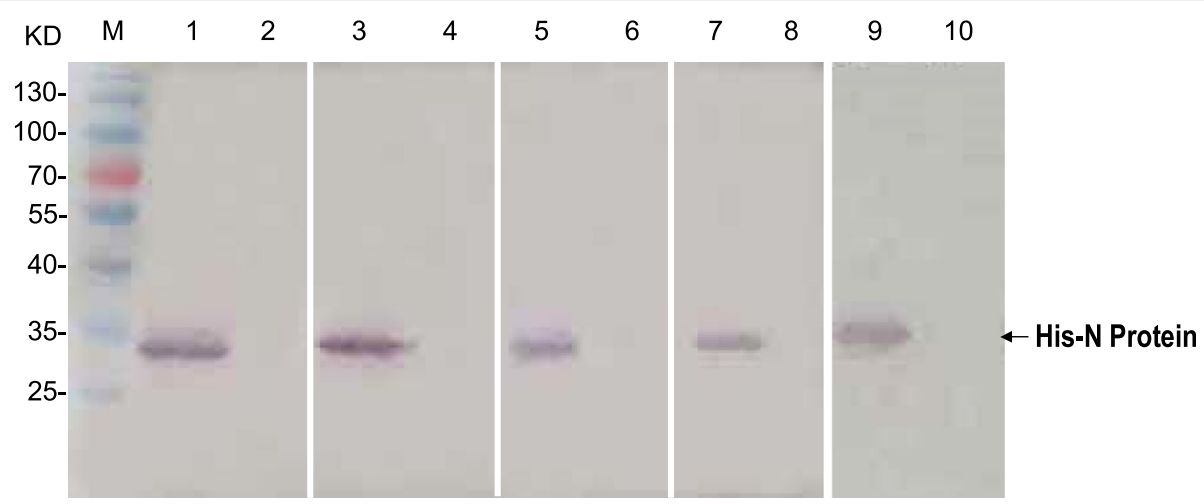

Fig. 2 The five MAbs specifically recognize the recombinant N protein of IYSV in Western blot. M, protein molecular weight marker; Lanes 1,3,5,7, and 9 were loaded with the protein extracts from the E. coli strain expressing the recombinant $N$ protein, but the lanes 2,4,6,8, and 10 were loaded with protein extracts from the E. coli strain expressing the empty vector. 1,2 were detected by 16D9; 3,4 were detected by 11C6; 5,6 were detected by 7F4; 7,18 were detected by $12 \mathrm{C} 10 ; 9,10$ were detected by $14 \mathrm{H} 12$

\section{The sensitivity of MIA in detecting IYSV}

Both ELISA and MIA are based on the reaction between the antibody and antigen. To compare the sensitivity of ELISA and MIA in detecting IYSV, a same set of 2-fold serial dilutions of IYSV-infected plant saps and the MAb 7F4 were used for detection by ELISA and MIA, respectively. The results showed that the ELISA assay could detect the IYSV from the 1:40 dilution of plant saps. In contrast, MIA could detect the IYSV from the 1:640 dilution of plant saps as the lowest, indicating that the sensitivity of MIA in detecting IYSV is 16-fold higher than that of ELISA (Table 3).

\section{Discussion}

Although MIA has been widely used for detecting animal viruses and other pathogens, its development and application for detecting plant viruses is very limited to date. With regard to the methods for detecting IYSV, ELISA and PCR-based assays for detection of IYSV have been reported $[18,19,30]$, but the highly sensitive and specific approaches for large-scale detection of IYSV are not reported in the literature, likely because of the lack of the specific antibodies against IYSV. In this study, we obtained the polyclonal antibody and five specific MAbs against IYSV (11C6, 12C10, 14H12, 7F4, and 16D9) by using the recombinant $\mathrm{N}$ protein of IYSV produced in $E$. coli (Fig. 1 and Table 1). The amino acid sequences of $\mathrm{N}$ protein from different IYSV isolates have high similarity, and thus the IYSV N protein is relatively conserved [12, 31, 32]. With these antibodies, we developed the TASELISA and MIA methods for detecting IYSV. Compared with the TAS-ELISA, we found that the sensitivity of MIA is much higher (16-fold) in detecting IYSV from the extracts of infected tobacco leaves when the same antibodies were used in both assays (Table 3). Among the five MAbs we obtained, the MAb 7F4 showed the best performance in MIA detection of IYSV in terms of the specificity and efficiency (Table 2). Thus, to obtain the antibodies against the target viruses or pathogens, particularly the specific MAbs with high sensitivity, is the prerequisite in establishing the MIA for detection of plant viruses.

In addition to the increased detection sensitivity, compared with TAS-ELISA, the MIA method we developed offers several other advantages. First, the MIA procedure is less time-consuming, because the whole process of MIA in detecting IYSV from infected plant leaves could be completed in about $2.5 \mathrm{~h}$. However, the normal TASELISA process would require $6-8 \mathrm{~h}$ for obtaining the final results. Second, the MIA method we developed for detecting IYSV showed high specificity. Typically, the specificity of MIA is predominantly determined by the specificity of the antibodies used and the procedure used for enriching the viruses or pathogens from the infected tissues [33]. To develop a high-specific MIA method for detecting IYSV, we used the polyclonal antibody to coat the magnetic beads for enrichment of IYSV from the extracts of infected leaves. We also generated the MAbs against IYSV and obtain theMAb 7F4 that shows high sensitivity and specificity to ISYV by performing the comparative analysis. In addition, the optimized conditions were set up to couple biotin and SA-RPE with the MAb 7F4. It is likely

Table 2 The specificity of MIA in detecting IYSV

\begin{tabular}{|c|c|c|c|c|c|c|c|c|c|c|}
\hline \\
\hline Virus & ArMV & TRSV & SLRSV & INSV (R.K) & INSV (DSMZ) & IYSV (DSMZ) & IYSV (R.K) & TSWV (R.K) & TSWV (DSMZ) & Control \\
\hline MFI value & 55 & 99 & 64 & 47 & 71 & 2916 & 25,110 & 86 & 54 & 62 \\
\hline
\end{tabular}


Table 3 The sensitivity of ELISA and MIA in detecting IYSV

\begin{tabular}{llll}
\hline samples & Dilution & \multicolumn{2}{l}{ MFI value } \\
\cline { 3 - 4 } & & MIA & ELISA \\
\hline Inoculated plant & $1: 10$ & 20,813 & 0.577 \\
Inoculated plant & $1: 20$ & 19,897 & 0.374 \\
Inoculated plant & $1: 40$ & 17,767 & 0.24 \\
Inoculated plant & $1: 80$ & 9865 & 0.178 \\
Inoculated plant & $1: 160$ & 5214 & 0.126 \\
Inoculated plant & $1: 320$ & 1212.5 & 0.110 \\
Inoculated plant & $1: 640$ & 233.5 & 0.122 \\
Inoculated plant & $1: 1280$ & 183 & 0.09 \\
Healthy control & $/$ & 98.0 & 0.082 \\
\hline
\end{tabular}

that the enrichment procedure, high specificity of 7F4 and optimized conditions together make the MIA method we developed with the high specificity. Indeed, the MIA we developed could specifically detect IYSV from the extracts of infected tobacco leaves, but not three Nepoviruses including ArMV, TRSV and SLRSV and two other Orthotospoviruses including INSV and TSWV (Table 2), given that most isolates of IYSV have high nucleotide sequence identity [2, 3]. Thirdly, MIA can be automated for highthroughput detection using pipetting robots and the Luminex analyzer. The MIA procedure we developed is easy to perform and even without the pipetting robots a hundred of samples can be easily distributed into wells of the plate using the standard pipette within couple minutes. Fourth, undoubtedly, the Luminex xMAP-based MIA method possesses potential broad usefulness in plant virus detection. The MIA procedure we developed can be easily adapted for detecting the other plant viruses, provided that there are specific antibodies against the target viruses available. Compared with the TAS-ELISA, in principle the Luminex xMAP-based MIA method could also be used for simultaneous detection of multiple pathogens including mix-infected viruses, although this needs to be demonstrated by future investigations.

\section{Conclusions}

We developed a Luminex xMAP-based MIA method for detection of IYSV in plants. We showed this is a sensitive, high-specific, easy to perform and cost-effective method. IYSV is a Orthotospovirus that infects most Allium species. Although both IYSV and TSWV, which is well-known as the most prevalent Orthotospovirus in the world, are transmitted by thrips, the occurrence of IYSV in the world is relatively scared and restricted in the Allium-growing countries/regions of the world. Its occurrence was also reported only in a few plant species. Thus, the MIA method we reported here would be particularly useful for detecting IYSV in plants, especially from the imported onions, to prevent its wide spread across the world.

\section{Abbreviations}

ArMV: Arabis mosaic virus; ELISA: enzyme-linked immunosorbent assay; INSV: Impatiens necrotic spot virus; IPTG: isopropylthio-b-galactosidebovine; IYSV: Iris yellow spot virus; MAbs: monoclonal antibodies; MFI: median fluorescent intensity; MIA: microsphere immunoassay; N: nucleocapsid; PBS: phosphate-buffered saline; SA-RPE: streptavidin R-phycoerythrin; SLRSV: Strawberry latent ringspot virus; TAS: triple antibodies-based sandwich; TRSV: Tobacco ringspot virus; TSWV: Tomato spotted wilt virus

\section{Acknowledgements}

We thank Professor R. Kormelink (Wageningen Agricultural University, The Netherlands) for his kindly supply of virus sources of IYSV, Tomato spotted wilt virus (TSWV) and Impatiens necrotic spot virus (INSV).

\section{Funding}

This work was supported by the funding National Key R\&D Program of China (2017YFC1200602) and (2015IK 240) from the General Administration of Quality Supervision, Inspection and Quarantine of the People's Republic of China (AQSIQ).

\section{Availability of data and materials}

Data sharing not applicable to this articles as no datasets were generated or analysed during the current study.

\section{Authors' contributions}

CY designed the study, analyze the data and drafted the manuscript, Cuiyun $Y$ participated in the cloning and expression of the $N$ gene. SS participated in the characterization of the MAbs. ZY participated in the development of MIA assay. XZ participated in the design of the study. JW* conceived of the study, participated in the production of the MAbs and revised the manuscript. All authors read and approved the final manuscript.

Ethics approval and consent to participate

Not applicable.

\section{Consent for publication}

Not applicable.

\section{Competing interests}

The authors declare that they have no competeing interests.

\section{Publisher's Note}

Springer Nature remains neutral with regard to jurisdictional claims in published maps and institutional affiliations.

\section{Author details}

${ }^{1}$ Shanghai Entry-Exit Inspection and Quarantine Bureau, Shanghai 200135, China. ${ }^{2}$ Institute of Biotechnology, Zhejiang University, Hangzhou 310058, China. ${ }^{3}$ Institute of Plant Protection, Chinese Academy of Agriculture Sciences, Beijing 10094, China.

Received: 25 December 2017 Accepted: 28 February 2018 Published online: 04 April 2018

\section{References}

1. Bag S, Schwartz HF, Cramer CS, Havey MJ, Pappu HR. Iris yellow spot virus (Tospovirus: Bunyaviridae): from obscurity to research priority. Mol Plant Pathol. 2015;16:224-37.

2. Baker HN, Murphy R, Lopez E, Garcia C. Conversion of a capture ELISA to a luminex XMAP assay using a multiplex antibody screening method. J Vis Exp. 2012;(65):1-7.

3. Bergervoet JHW, Peters J, Beckhoven JRCM, Bovenkamp GW, Jacobson JW, Wolf JM. Multiplex microsphere immuno-detection of potato virus $Y, X$ and PLRV. J Virol Methods. 2008;149:63-8.

4. Charlermroj R, Himananto O, Seepiban C, Kumpoosiri M, Warin N, Oplatowska M, Gajanandana O, Grant IR, Karoonuthaisiri N, Elliott CT. Multiplex detection of plant pathogens using a microsphere immunoassay technology. PLoS One. 2013;8(4):1-11.

5. Cortês I, Livieratos IC, Derks A, Peters D, Kormelink R. Molecular and serological characterization of Iris yellow spot virus, a new and distinct tospovirus species. Phytopathology. 1998;88(12):1276-82. 
6. Gera A, Cohen J, Salomon R, Raccah B. Iris yellow spot tospovirus detected in onion (Allium cepa) in Israel. Plant Dis., 1998;82(1):127.

7. Cordoba-Selles C, Martınez-Priego L, Munoz-Gomez R, Jorda-Gutierrez C. Iris yellow spot virus: a new onion disease in Spain. Plant Dis. 2005;89:1243.

8. Coutts BA, McMichael LA, Tesoriero L, Rodoni BC, Wilson CR, Wilson AJ, Persley DM, Jones RAC. Iris yellow spot virus found infecting onions in three Australian states. Australas Plant Pathol. 2003;32:555-7.

9. Doi M, Zen S, Okuda M, Nakamura H, Kato K, Hanada K. Leaf necrosis disease of lisianthus (Eustoma grandiflorum) caused by Iris yellow spot virus. Japanese J Phytopathology. 2003;69:181-8.

10. Gent DH, Mohan SK, du Toit LJ, Pappu HR, Fichtner SF, Schwartz HF. Iris yellow spot virus: an emerging threat to onion bulb and seed production. Plant Dis. 2006;90(12):1468-80.

11. Gawande SJ, Gurav VS, Ingle AA, Gopal J. First report of Iris yellow spot virus infecting Allium tuberosum in India. Plant Dis. 2014;98(8):1161.

12. Hafez EE, El-Morsi AA, El-Shahaby OA, Abdelkhalek AA. Occurrence of Iris yellow spot virus from onion crops in Egypt. Virus Disease. 2014;25:455-9.

13. Hall JM, Mohan K, Knott EA. Tospoviruses associated with scape blight of onion (Allium cepa) seed crops in Idaho. Plant Dis. 1993;77:952.

14. Hsu HT, Vongasitom D, Lawson RL, Wand M, Gonsalves D. Splenocytes of mice with induced immunological tolerance to plant antigens for construction of hybridomas secreting Tomato spotted wilt virus-specific antibodies. Phytopathology. 1990:80:158-62.

15. Jiang JX, Chen ZX, Zhou XP. Production of a monoclonal antibody to Sugarcane mosaic virus and its application for virus detection in China. J Phytopathol. 2003;151:361-4.

16. Lim MS, Kim SM, Choi SH. Simultaneous detection of three lily-infecting viruses using a multiplex Luminex bead array. J Virol Methods. 2016;231:34-7.

17. Mallaupoma ZC, Inguil Rojas EH, Gitaitis RD. Phylogenetic analysis of the N gene links Georgia strains of Iris yellow spot virus to strains from Peru. Phytopathology. 2006;96:S84.

18. Mullis SW, Gitaitis RD, Nischwitz C, Csinos AS, Rafael Mallaupoma ZC, Inguil Rojas EH. First report of onion (Allium cepa) naturally infected with Iris yellow spot virus (family Bunyaviridae, genus Tospovirus) in Peru. Plant Dis. 2006;90:377.

19. Mumford RA, Glover R, Daly M, Nixon T, Harju V, Skeltonlris A. Iris yellow spot virus (IYSV) infecting lisianthus (Eustoma grandiflorum ) in the UK: first finding and detection by real-time PCR. Plant Pathol. 2008:57:768.

20. Muniyappa V, Swanson MM, Duncan GH, Harrison BD. Particle purification, properties and epitope variability of Indian tomato leaf curl geminivirus. Ann Appl Biol. 1991;118:595-604.

21. Nischwitz C, Mullis SW, Csinos AS, Langston DB, Sparks AN, Torrance RL, Rafael Mallaupoma ZC, Inguil Rojas EH, Gitaitis RD. Phylogenetic analysis of the $\mathrm{N}$ gene links Georgia strains of Iris yellow spot virus to strains from Peru. Phytopathology. 2006;96:S84.

22. Nischwitz C, Gitaitis RD, Mullis SW, Csinos AS, Langston DB. First report of Iris yellow spot virus in spiny Sowthistle (Sonchus asper) in the United States. Plant Dis. 2007a;91:1518.

23. Nischwitz C, Pappu HR, Mullis SW, Sparks AN, Langston DB, Csinos AS, Gitaitis RD. Phylogenetic analysis of Iris yellow spot virus isolates from onion (Allium cepa) in Georgia (U.S.a.) and Peru. J Phytopathol. 2007b; 155:531-5.

24. Pappu HR, du Toit $\sqcup$, Schwartz HF, Mohan K. Sequence diversity of the nucleoprotein gene of Iris yellow spot virus (genus Tospovirus, family Bunyaviridae) isolates from the western region of the United States. Arch Virol. 2006;151:1015-23.

25. Pappu HR, Rosales IM, Druffel KL. Serological and molecular assays for rapid and sensitive detection of Iris yellow spot virus infection of bulb and seed onion crops. Plant Dis. 2008;92(4):588-94.

26. Peters J, Sledz W, Bergervoet JHW, van der Wolf JM. An enrichment microsphere immunoassay for the detection of Pectobacterium atrosepticum and Dickeya dianthicola in potato tuber extracts. Eur J Plant Pathol. 2007;117:97-107.

27. Pozzer L, Bezerra IC, Kormelink R, Prins M, Peters D, Resende RDO, de Avila AC. Characterization of a tospovirus isolate of Iris yellow spot virus associated wit a disease in onion fields in Brazil. Plant Disease. 1999:83:345-50.

28. Rosales M, Pappu HR, López L, Mora R, Aljaro A. Iris yellow spot virus in onion in Chile. Plant Dis. 2005:89:1245.

29. Shin $Y$, Rho J. Development of a PCR diagnostic system for Iris yellow spot tospovirus in quarantine. Plant Pathol J. 2014:30(4):440-4
30. Vignali DAA. Multiplexed particle-based flow cytometric assays. J Immunol Methods. 2000:243(1-2):243-55.

31. Srinivasan R, Sundaraj S, Pappu H, Diffie S, Riley DG, Gitaitis R. Transmission of Iris Yellow Spot Virus by Frankliniella fusca and Thrips tabaci (Thysanoptera: Thripidae). J Econ Entomol. 2012;105(1):40-7.

32. Wu JX, Yu L, Li L, Hu JQ, Zhou JY, Zhou XP. Oral immunization with transgenic rice seeds expressing VP2 protein of infectious bursal disease virus induces protective immune responses in chickens. Plant Biotechnol J. 2007:5:570-8.

33. Yu C, Wu J, Zhou X. Detection and subgrouping of Cucumber mosaic virus isolates by TAS-ELISA and immunocapture RT-PCR. J Virol Methods. 2005; 123:155-61.

\section{Submit your next manuscript to BioMed Central and we will help you at every step:}

- We accept pre-submission inquiries

- Our selector tool helps you to find the most relevant journal

- We provide round the clock customer support

- Convenient online submission

- Thorough peer review

- Inclusion in PubMed and all major indexing services

- Maximum visibility for your research

Submit your manuscript at www.biomedcentral.com/submit
) Biomed Central 